\title{
Climate Change and Potato Production in Contrasting South African Agro-ecosystems 1. Effects on Land and Water Use Efficiencies
}

\author{
A. J. Haverkort ${ }^{\star}$ A. C. Franke • F. A. Engelbrecht \\ -J. M. Steyn
}

\begin{abstract}
Explorations of the impact of climate change on potential potato yields were obtained by downscaling the projections of six different coupled climate models to high spatial resolution over southern Africa. The simulations of daily maximum and minimum temperatures, precipitation, wind speed, and solar radiation were used as input to run the crop growth model LINTUL-Potato. Pixels representative for potato growing areas were selected for four globally occurring agro-ecosystems: rainy and dry winter and summer crops. The simulated inter-annual variability is much greater for rainfall than for temperature. Reference evapotranspiration and radiation are projected to hardly decline over the 90 -year period, whilst temperatures are projected to rise significantly by about $1.9{ }^{\circ} \mathrm{C}$. From literature, it was found that radiation use efficiency of potato increased with elevated $\mathrm{CO}_{2}$ concentrations by almost $0.002 \mathrm{~g} \mathrm{MJ}^{-1} \mathrm{ppm}^{-1}$. This ratio was used to calculate the $\mathrm{CO}_{2}$ effect on yields between 1960 and 2050, when $\mathrm{CO}_{2}$ concentration increases from 315 to $550 \mathrm{ppm}$.
\end{abstract}

A. J. Haverkort

Plant Research International, Wageningen University and Research Center, P.O. Box 616, 6700 AP Wageningen, The Netherlands

A. J. Haverkort $\left({ }^{\star}\right) \cdot$ J. M. Steyn

Department of Plant Production and Soil Science, University of Pretoria, Private Bag X20, Hatfield 0028 , South Africa

e-mail: anton.haverkort@wur.nl

\section{A. C. Franke}

Plant Production Systems Group, Wageningen University and Research Center, P.O. Box 430, 6700 AK Wageningen, The Netherlands

\section{F. A. Engelbrecht}

Climate Studies, Modelling and Environmental Health, CSIR Natural Resources and the Environment, Pretoria, South Africa

\section{F. A. Engelbrecht}

School of Geography, Archaeology and Environmental Studies, University of the Witwatersrand, Private Bag 3, Wits 2050, South Africa 
Within this range, evapotranspiration by the potato crop was reduced by about $13 \%$ according to literature. Simulated yield increase was strongest in the Mediterraneantype winter crop $(+37 \%)$ and least under Mediterranean summer $(+12 \%)$ and relatively warm winter conditions $(+14 \%)$ closer to the equator. Water use efficiency also increased most in the cool rainy Mediterranean winter $(+45 \%)$ and least so in the winter crop closer to the equator $(+14 \%)$. It is concluded from the simulations that for all four agro-ecosystems possible negative effects of rising temperatures and reduced availability of water for potato are more than compensated for by the positive effect of increased $\mathrm{CO}_{2}$ levels on water use efficiency and crop productivity.

Keywords Climate change $\cdot \mathrm{CO}_{2}$-concentration $\cdot$ Contrasting agro-ecosystems $\cdot$ Potato Water use efficiency. Yield

\section{Introduction}

In South Africa, potato is grown on almost 51,000 ha, and current average yields amount to $41 \mathrm{Mgha}^{-1}$ (Potatoes South Africa 2011). The areas, growing conditions, and production are shown in Table 1, and the geographical distribution is presented in Fig. 1. The cultivated area declined over recent years, but the total production remained stable as yields increased strongly due to the use of irrigation and introduction of new cultivars.

South Africa is exposed to different climates: a continental climate over the interior with dry winters and rainy summers and a Mediterranean climate in the south-western coastal areas, with dry warm summers and rainy winters (Taljaard 1986). Potatoes are grown in both seasons of these climatic regions (dry or rainy winters and summers), which makes it an ideal case to study productivity and water use efficiency of potato as affected by climate change. In Limpopo, in the north-east of the country, the rainy summers are too hot for potato production due to the low

Table 1 South African potato production data for 2010 (Potatoes SA 2011

\begin{tabular}{lcccl}
\hline Region & $\begin{array}{l}\text { Production } \\
\text { area (ha) }\end{array}$ & $\begin{array}{l}\text { Relative share } \\
\text { in area }\end{array}$ & $\begin{array}{l}\text { Production } \\
(1,000 \mathrm{t})\end{array}$ & Growing conditions \\
\hline Limpopo & 9,197 & $18 \%$ & 398 & Dry winter \\
Eastern Free State & 8,525 & $17 \%$ & 256 & Wet summer \\
Sandveld & 7,104 & $14 \%$ & 317 & Wet winter and dry summer \\
Western Free State & 6,109 & $12 \%$ & 301 & Wet summer \\
KwaZulu Natal & 4,063 & $8 \%$ & 153 & Wet summer \\
Mpumalanga & 2,628 & $5 \%$ & 120 & Wet summer \\
North West & 2,360 & $5 \%$ & 111 & Wet summer \\
Loskop Valley & 2,424 & $5 \%$ & 80 & Wet summer \\
Other areas & 8,361 & $16 \%$ & 214 & \\
Total & 50,771 & & 2,090 & \\
\hline
\end{tabular}

Regions in bold indicate where the effect of climate change was evaluated 


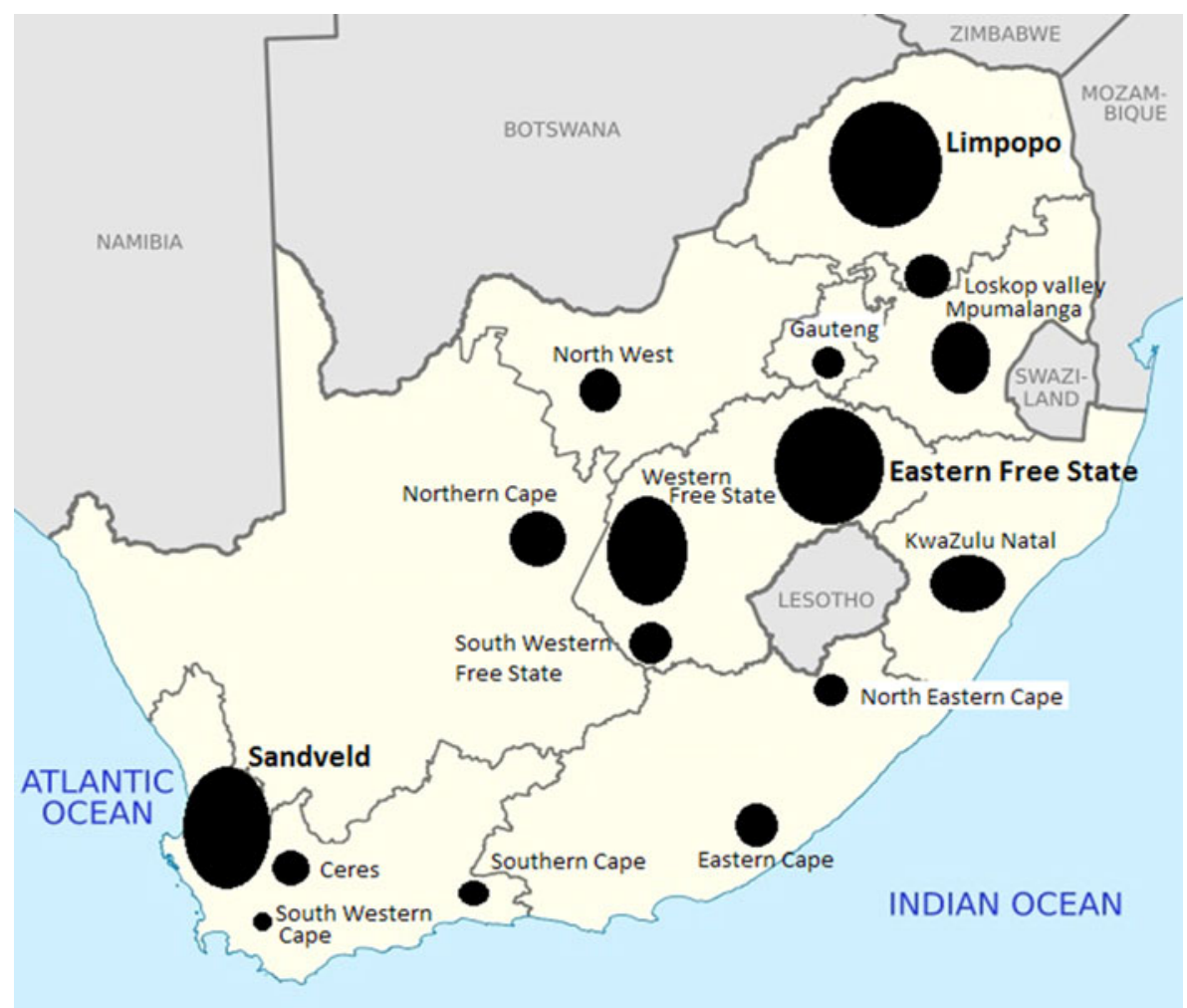

Fig. 1 Potato production areas in South Africa and their relative importance

altitude $(1,100 \mathrm{~m})$, and therefore potatoes are grown in winter and early spring under irrigation. In the highlands of the eastern Free State, which is further from the equator and at 1,650 m altitude, frost inhibits the cultivation of potatoes in winter, so this site represents a typical potato production area with a rainy summer. In the Mediterranean Sandveld, which is almost at sea level in the south-west, potato is produced in the dry summer near the coast where winds from the Atlantic Ocean prevent too high summer temperatures, as well as in the rainy winter when the nearby ocean prevents the occurrence of frost. It should be noted that, in all potato production systems in South Africa, whether in crops grown in a rainy season or not, (additional) irrigation is usually a necessity to achieve economically acceptable yields, as overall rainfall is low and erratic (Potatoes South Africa 2011). Irrigation is usually applied through center-pivot irrigation systems.

The $\mathrm{CO}_{2}$ concentration of the atmosphere increased from 315 to $380 \mathrm{ppm}$ between 1960 and 2000 (Nakicenovic and Swart 2000). Model forecasts suggest that, by 2050 , the atmospheric $\mathrm{CO}_{2}$ concentration will have increased to about $550 \mathrm{ppm}$ under the A2 scenario of the Special Report on Emission Scenarios (SRES) (Nakicenovic et al. 2000). This implies a $235 \mathrm{ppm}$ increase since 1960, or a doubling of the $\mathrm{CO}_{2}$ concentration compared with the pre-industrial era.

Studies by Schapendonk et al. $(1995 ; 2000)$ showed that potato yields increased on average by $36 \%$ when $\mathrm{CO}_{2}$ concentration in open-top chambers was doubled from 350 to $700 \mathrm{ppm} \mathrm{CO}_{2}$. This represents a yield increase of $0.11 \%$ per ppm increase in 
$\mathrm{CO}_{2}$ concentration of the atmosphere. The yield response differed between years and among varieties, with late cultivars benefiting more from increased $\mathrm{CO}_{2}$ levels. The authors hypothesized that, under higher $\mathrm{CO}_{2}$ concentration, more assimilates become available in the leaves, enhancing the production and benefiting the activity of the sink organs (tubers), thus resulting in a substantial enhancement of final yield. The late variety may have benefited more because of a relatively earlier tuber formation. Schapendonk et al. (2000) also noticed that elevated $\mathrm{CO}_{2}$ levels did not affect light interception and hardly affected total leaf formation. The higher productivity was primarily related to a higher photosynthetic capacity, which was limited by the plant's ability to allocate assimilates to the tubers. Similarly, Rosenzweig and Hillel (1998) recorded yield increases of up to $51 \%$ for various crops, including potato, when doubling the $\mathrm{CO}_{2}$ concentration. A concerted program of the Commission of the European Union in 1998 and 1999 funded a European network of experiments in open-top chambers, free air $\mathrm{CO}_{2}$ enrichment (FACE), and a CHIP (Changing Climate Impact on Potato Yield and Quality) project, as described by Vorne et al. (2002). Experimental and modelling research was carried out to investigate the effects of increasing atmospheric $\mathrm{CO}_{2}$ and ozone concentrations under different climatic conditions on potato cv. Bintje (De Temmerman et al. 2002). These data were used by Wolf and Van Oijen (2003) to simulate potato yields in southern and northern Europe. They concluded that "Climate change gave increases in irrigated yields of 2,000$4,000 \mathrm{kgha}^{-1}$ dry matter in most regions of the EU, mainly due to the positive response to increased $\mathrm{CO}_{2}$." Assuming tubers have a dry matter concentration of $20 \%$, this means fresh yield increases between 10 and $20 \mathrm{Mgha}^{-1}$. T h e F A C E experiments (Miglietta et al. 1998; Magliulo et al. 2003) showed the highest tuber yield increases (between 29\% and 54\%) with a $\mathrm{CO}_{2}$ increase in the range from 370 to $550 \mathrm{ppm}$. Jaggard et al. (2010) suggested a 36\% increase in potato yields due to the increased concentration of $\mathrm{CO}_{2}$ and a $7.5 \%$ decrease in yield due to the increased ozone level (also assessed in the FACE and CHIP trials), resulting in a net yield increase of $28.5 \%$. This is in line with the findings of Schapendonk et al. (2000) and the expected 28.5\% yield increase (Jaggard et al. 2010) when $\mathrm{CO}_{2}$ concentration reaches $550 \mathrm{ppm}$ and $\mathrm{O}_{3}$ concentration $60 \mathrm{ppb}$.

The experiments reported by the authors mentioned above showed increased yields at levels of supply of nutrients and of water to the crop as recommended or customary for crops in their respective environments. Crops grown at higher $\mathrm{CO}_{2}$ levels were supplied with the same amount of nutrients and water as those grown under ambient conditions. A higher uptake was not compensated by additional supply in the trials reported by Jaggard et al. (2010). For potato, therefore, higher yields will also lead to higher uptake of, e.g. nitrogen, so a higher nitrogen use efficiency of the available nitrogen.

According to Jaggard et al. (2010) potato (a C3 crop) will benefit most from rising $\mathrm{CO}_{2}$ levels compared with other crops. Other $\mathrm{C} 3$ crops, such as wheat and rice, showed a benefit of only about $6 \%$, while $\mathrm{C} 4$ crops do not benefit from $\mathrm{CO}_{2}$ enrichment at all and will suffer from increased ozone levels, leading to between $5 \%$ (maize) and $7.5 \%$ (sugar cane) yield reduction.

Various authors (Eamus 1991; Pospisilova and Catsky 1999; Schapendonk et al. 2000) argued that greater intracellular $\mathrm{CO}_{2}$ concentration due to increased atmospheric $\mathrm{CO}_{2}$ concentration leads to a smaller stomatal aperture and reduced water losses through transpiration from individual leaves, which could possibly lead to greater 
water use efficiency. In the trial by Magliulo et al. (2003), water use of potato decreased by $11 \%$ when $\mathrm{CO}_{2}$ increased from 370 to $550 \mathrm{ppm}$. This, combined with a yield increase of $53 \%$, resulted in an improved water use efficiency (WUE) of up to $70 \%$. Similarly, Jaggard et al. (2010) observed an 11\% decrease in water use during a crop season of unaltered length, when the $\mathrm{CO}_{2}$ concentration increased with $190 \mathrm{ppm}$. This means an increase in WUE of $0.058 \% \mathrm{ppm}^{-1} \mathrm{CO}_{2}$. Fleisher et al. (2008) also reported lower transpiration rate and substantially higher WUE for potato plants grown under elevated $\mathrm{CO}_{2}$ conditions (740 ppm).

Hijmans (2003) predicted global potato yield decreases of up to $32 \%$ by 2070 without adaptation and up to $18 \%$ with adaptation through the shifting of planting times and suggested breeding for heat adaptation, due to the likely increase in global temperatures by over $3{ }^{\circ} \mathrm{C}$. He, however, did not take the benefit of increased $\mathrm{CO}_{2}$ levels on growth into consideration, so his conclusions ignored the beneficial aspect of atmospheric $\mathrm{CO}_{2}$ enrichment. Supit et al. (2012) concluded that "Crops planted in spring (potato, sugar beet) initially benefit from the $\mathrm{CO}_{2}$ increase, however, as time progresses, increasing temperatures reduce these positive effects. By the end of the century, yields decline in southern Europe and production may only be possible if enough irrigation water is available. In northern Europe, depending on the temperature and $\mathrm{CO}_{2}$ concentration increases, yields either stagnate or decline. However, in some of the cooler regions, yield increase is still possible." These authors used the 'Crop Growth Monitoring System' consisting of weather monitoring, crop growth modelling (the World Food Studies (WOFOST) model) and statistical methods that assist in yield forecasting. The negative aspects of climate change that these authors expect toward the end of the century are due to expected reduction of precipitation. This aspect of climate change, however, is surrounded with the greatest degree of uncertainty (e.g., NASA 2013).

In contrast to some of the studies mentioned above, e.g., the study by Wolf and Van Oijen (2003) in the European Union, such studies have not been conducted for South Africa before. Given the expected increase in average temperatures for southern Africa and the sensitivity of potato to heat stress, we hypothesize that the impact of climate change on potato production and water use efficiency will be negative. This is of major concern, since potato is the most important vegetable crop in South Africa, and potato production is the main economic activity in some production areas, such as the Western Cape Sandveld. Moreover, fresh water is expected to become increasingly scarce and a prime constraint to agricultural productivity in South Africa. Therefore, the objectives of this study were to explore the influence of climate change as derived from various downscaled coupled climate models on productivity and water use efficiency of the potato crop in South African conditions.

Models can be applied at various levels from the genome to the crop (Yin and Struik 2008) and further up to the agro-ecosystems level. For this study, we used simulated 90-year climate datasets (1961-2050) and a crop growth model with temperature, solar radiation, $\mathrm{CO}_{2}$ concentration, rainfall, and reference evapotranspiration as input data: LINTUL-Potato (Spitters 1990; Kooman and Haverkort 1994). The WOFOST model mentioned above and LINTUL hardly differ in assumptions. We decided to use LINTUL as it has more often been used for potato modelling, it has been validated under various agro-ecological conditions and its radiation use efficiency (RUE) and WUE parameter values can conveniently be adapted to 
accommodate the yield and water use responses to climate change reported by Jaggard et al. (2010). Moreover, differences between the models may show some systematic deviations, but differences between various climate scenarios and conclusions derived from them are not likely influenced by the choice of the crop growth model. The study presented here is based on current crop management. In a companion paper, we will look into possible adaptation strategies such as altered planting dates and harvest strategies (Franke et al. 2013). In a third study, we focus on possible repercussions of climate change on relative development rates of pests and diseases and control strategies (Van der Waals et al. 2013).

\section{Material and Methods}

\section{Climate Change Models and Output Data}

The detailed simulations of present-day and future climate over southern Africa applied in this study were obtained by downscaling the output of six different coupled climate models (CGCMs), which contributed to Assessment Report Four of the Intergovernmental Panel on Climate Change, to high spatial resolution over southern Africa. The downscaling was performed using a variable-resolution global circulation model, the conformal-cubic atmospheric model (CCAM) of the Commonwealth Scientific and Industrial Research Organisation. A multiple-nudging procedure was used to obtain the high-resolution simulations. First, the bias-corrected sea-surface temperatures and sea-ice concentration of the CGCMs were used to force CCAM at its lower boundary, to perform global simulations of climate over the period 1961-2050, at a horizontal resolution of about $200 \mathrm{~km}$. These simulations were subsequently used to force a second ensemble of higher resolution CCAM simulations over southern Africa. In these simulations, the model was applied in stretched-grid mode over southern Africa and nudged within the output of the $200 \mathrm{~km}$ resolution CCAM simulations. In the stretchedgrid simulations, the model resolution was about $60 \mathrm{~km}$ over southern Africa, decreasing to about $400 \mathrm{~km}$ in the far-field. All simulations were obtained using the A2 SRES scenario. For a more in-depth description of the experimental design, including a description of a CCAM equation set and parameterization schemes, see Engelbrecht et al. (2011). CCAM has been shown to represent many aspects of the southern African climate, such as the seasonal rainfall cycle, frequency of extreme rainfall events, and inter-annual rainfall variability, satisfactorily (Engelbrecht et al. 2009; 2011; 2013).

Each of the six different downscalings constitutes of 90 years (1961 to 2050) of daily weather data (maximum and minimum temperature ( $T \max$ and $T \mathrm{~min}$ ), solar radiation, precipitation, maximum and minimum relative humidity, and wind speed) for use in the crop model and to calculate evapotranspiration (ETo) values. Monthly average minimum and maximum temperatures and rainfall data generated were compared with actual data sets from weather stations in each of the selected four regions. The names, coordinates, and elevations of the weather stations used to calibrate the simulations in each region are given in Table 2 . The regional climate model simulations generally overestimated current temperatures by about $1{ }^{\circ} \mathrm{C}$ and the amount of rainfall by about $30 \%$. The downscaled data were subsequently bias-corrected. The observed climatology of each site was compared with each particular regional downscaling over the same 
Table 2 Names and locations of weather stations used to calibrate climate change model predictions in each region

\begin{tabular}{lllcc}
\hline Region & Station name & Latitude & Longitude & Elevation (m) \\
\hline Limpopo & Dendron & $23.46079 \mathrm{~S}$ & $29.23272 \mathrm{E}$ & 1,120 \\
Eastern Free State & Reitz-Bethlehem & $28.48281 \mathrm{~S}$ & $28.82521 \mathrm{E}$ & 1,668 \\
Sandveld & Sandberg & $32.28998 \mathrm{~S}$ & $18.56610 \mathrm{E}$ & 102 \\
\hline
\end{tabular}

period, and temperature and rainfall values were reduced according to the average biases identified at each agro-ecosystem, in practice, about $25 \%$ reduction of those modelled for the daily data over the complete period of 90 years.

\section{Crop Growth Model}

The LINTUL crop growth model used in the present study - similar to the one used by Franke et al. (2011) to calculate current potential potato yields and water use efficiencies in the Sandveld region - simulates potato dry matter production based on the amount of intercepted radiation by its green foliage and a conversion factor for RUE (Spitters 1990), following the approach of Kooman and Haverkort (1994) by calculating the temperature-dependent phenological development of a potato crop. Higher temperatures lead to earlier crop emergence and a more rapid initial leaf growth, resulting in increased interception of solar radiation at early stages of crop growth, a more rapid maturation of the crop, and a reduced length of the growing cycle from planting to harvest. Moreover, very high temperatures reduce photosynthesis and increase respiration and thereby reduce the radiation use efficiency, and thus biomass accumulation.

We simulated shoot growth, foliar expansion, biomass accumulation, and tuber growth on a day-to-day basis. Climate input data required by the model include daily minimum and maximum temperatures, incoming solar radiation and rainfall, reference evapotranspiration, and $\mathrm{CO}_{2}$ concentration. Management input data include the depth and date of planting. Accumulated degree days from planting (with a base temperature of $2{ }^{\circ} \mathrm{C}$ ) determines the time to crop emergence, leaf area development, and the time of crop termination. The leaf area index (LAI) increases exponentially from crop emergence until a leaf area index of 0.75 is achieved. Thereafter, its development depends on temperature and water availability until a full crop cover is reached (LAI $>3$ ). Daily biomass growth is calculated using the crop's LAI, light interception (using an extinction coefficient of 1 (Spitters and Schapendonk 1990)), and the RUE (1.25 g dry matter $\mathrm{MJ}^{-1}$ of intercepted global radiation). In the model, photosynthesis capacity is reduced when the average day temperature falls below $16{ }^{\circ} \mathrm{C}$ or when the maximum temperature exceeds $30^{\circ} \mathrm{C}$ and is completely halted at temperatures below $2{ }^{\circ} \mathrm{C}$ and above $35{ }^{\circ} \mathrm{C}$ (Kooman and Haverkort 1994). The harvest index for all growing conditions was set at 0.75 (Kooman and Haverkort 1994), and simulated yields are presented as tuber fresh matter, assuming a dry matter concentration of $20 \%$.

Daily evapotranspiration (ET) was calculated from the Penman-Monteith grass reference ETo (Smith et al. 1996) multiplied by a crop-specific coefficient $\left(K_{\mathrm{c}}\right)$ according to the procedure recommended by Allen et al. (1996). Daily ETo values 
were calculated using the daily maximum and minimum temperatures, relative humidity, wind speed, and solar radiation as input parameters. Evaporation from the soil was quantified following Ritchie (1972), who calculated that a soil with an average water holding capacity that is wetted every 4 days by irrigation or rain has an evaporation rate that is one third of ETo until emergence of the crop. Thereafter, evaporation from the soil decreases linearly with ground cover (calculated from LAI) to $10 \%$ of ET at full ground cover at the LAI value of 3 .

Both RUE and the crop coefficient $\left(K_{\mathrm{c}}\right)$ used to derive ET from ETo are affected by changing $\mathrm{CO}_{2}$ levels. Jaggard et al. (2010) assumed a net yield increase resulting from $\mathrm{CO}_{2}$ and $\mathrm{O}_{3}$ increase of $28.5 \%$ between 2010 and 2050, with an expected $\mathrm{CO}_{2}$ concentration increase of $190 \mathrm{ppm}$ (the FACE experiments took place around the year 2000 with a $\mathrm{CO}_{2}$ concentration of $360 \mathrm{ppm}$ ). The relative increase (after 1990) or decrease (before 1990) in RUE per ppm $\mathrm{CO}_{2}$ change is therefore $0.15 \%$ of $1.25 \mathrm{~g}$ $\mathrm{MJ}^{-1}=0.001875 \mathrm{~g} \mathrm{MJ}^{-1} \mathrm{ppm}^{-1} \mathrm{CO}_{2}$. Similarly, the impact of changing $\mathrm{CO}_{2}$ levels on the crop coefficient was modelled. Jaggard et al. (2010) assumed an $11 \%$ decrease in water use during a crop season of unaltered length between 1990 and 2050 when the $\mathrm{CO}_{2}$ concentration increased with $190 \mathrm{ppm}$. Hence, between 1960 (315 ppm) and 2050 (550 ppm), the crop is expected to use $13.6 \%$ less water if other climatic conditions remain the same. The crop coefficient was thus reduced from 1.20 in 1990 to 1.07 in 2050 and increased before 1990 as a function of atmospheric $\mathrm{CO}_{2}$ levels. The investigations to which Jaggard et al. (2010) refer mention responses of final potato tuber yield to increased $\mathrm{CO}_{2}$ levels. This implies that they have taken into account any potential alteration in dry matter allocation patterns (to, e.g., leaves, stems and roots), as well as possible differences between the ratio of photosynthesis and respiration. Our approach therefore to relate past and future RUE to total dry matter production, assuming a harvest index of 0.75 , is based on the same experimental evidence.

To estimate ET, WUE, and drainage, we calculated a daily water balance using the plant available water of the most prominent soil in any region. When rainfall was in excess of what the soil can hold, it will not be available to the plant, as it may drain below the rooting zone (assumed to be $0.5 \mathrm{~m}$ deep throughout South Africa when running the models). Farmers were assumed to irrigate when $50 \%$ of the plant available water has depleted and may have irrigated just prior to an excessive rainstorm (then all precipitation is lost through drainage) or may have been about to irrigate when the rainfall event took place (then an amount equal to $50 \%$ of the plant available water is utilized and the rest is lost through drainage). We therefore assumed that only daily rainfall that is not in excess of $25 \%$ of the plant available water was available for crop growth. We also assumed that water was available for irrigation whenever needed.

We ran the model for four contrasting agro-ecosystems for the data in pixels in which we knew potato is an important part of the cropping system (Fig. 1, Table 1) and to cover the four combinations of summer and winter crops with and without significant precipitation during the growing season:

1. Sandveld (Leipoldville) winter crop planted on March 15 with cycle of 110 days (wet winter), coordinates: $18.5^{\circ} \mathrm{E} 32.5^{\circ} \mathrm{S}$.

2. Sandveld (Leipoldville) summer crop planted on September 15 with cycle of 130 days (dry summer), coordinates: $18.5^{\circ} \mathrm{E} 32.5^{\circ} \mathrm{S}$. 
3. Eastern Free State (Reitz-Bethlehem) planted on Oct 15 with cycle of 120 days (wet summer), coordinates: $28.5^{\circ} \mathrm{E} 28.0^{\circ} \mathrm{S}$.

4. Limpopo (Dendron) planted on July 15 with cycle of 130 days (dry winter), coordinates: $29.0^{\circ} \mathrm{E} 23.5^{\circ} \mathrm{S}$

\section{Data Handling and Presentation}

In Figs. 2, 3, 4, 5, 6, and 7, not the whole year average but the average during the period between planting and harvest (between 110 and 130 days, depending on site and season) is presented. The two solid lines in the graphs represent the maximum and minimum values calculated using any of the six downscalings, and the dots represent the average value of the calculations from all six weather sets. With these average values, a linear regression analysis was carried out based on the equation $y=a+b x$, where $y$ is the dependent variable, the value of a weather or crop parameter, and $x$ the independent variable, i.e., the year between 1961 and 2050. The coefficient of determination $\left(R^{2}\right)$ from the regression analyses represents the proportion of variation of $y$ explained by variation of $x$. The 1960 and 2050 values in Tables 3 and 4 were calculated using the equation derived from linear regression; the $\Delta$ values per year allow for easy comparison between sites and seasons. Tables 3 and 4 also show results of regression analyses of data not shown in the figures.

All yields are given as fresh tuber yield (assuming 20\% dry matter). The WUE was calculated as the fresh tuber yield divided by the total evapotranspiration (from plant and soil). Possible irrigation losses and drainage were not considered here.

\section{Results}

\section{Weather and Climate Change for the Four Contrasting Agro-Ecosystems}

The Tmax and Tmin values of the Sandveld summer, the eastern Free State, and Limpopo are comparable (Fig. 2). However, Tmax values of the Sandveld in summer and Limpopo more frequently exceed $30^{\circ} \mathrm{C}$, especially in the next decades, reducing the photosynthesis capacity of the potato crop. Temperatures of the Sandveld in winter are considerably lower than in the other situations. The increase in $T$ max over a century is about $2.3^{\circ} \mathrm{C}$ at the coastal Sandveld and over $2.6^{\circ} \mathrm{C}$ at the inland sites. Tmin increases on average by $1.8^{\circ} \mathrm{C}$ at the coast and $2.5^{\circ} \mathrm{C}$ inland. The temperatures show little variation among years and increase steadily as is shown by the high coefficient of determination values of around 0.8 (Table 3 ).

Rainfall data for the four agro-ecosystems are shown in Fig. 3. The "dry summer" and "dry winter" situation still have some rainfall $(60$ and $106 \mathrm{~mm}$, respectively, in 1960). The variation over years is much higher than for temperatures, and also the variation between the different downscaled sets is greater, as shown by the distance between the two solid lines (not shown for the Sandveld situation because summer and winter lines interfered too much). Due to the greater variation between years, the coefficient of determination values are very low (less than 0.14) (Table 3), indicating that the decrease in rainfall of 25,9 , and $10 \mathrm{~mm}$ in the Sandveld winter, summer, and Limpopo, respectively, and an increase of $10 \mathrm{~mm}$ in the Free State are associated with a high degree of uncertainty, although a downward trend for most situations is clear. 

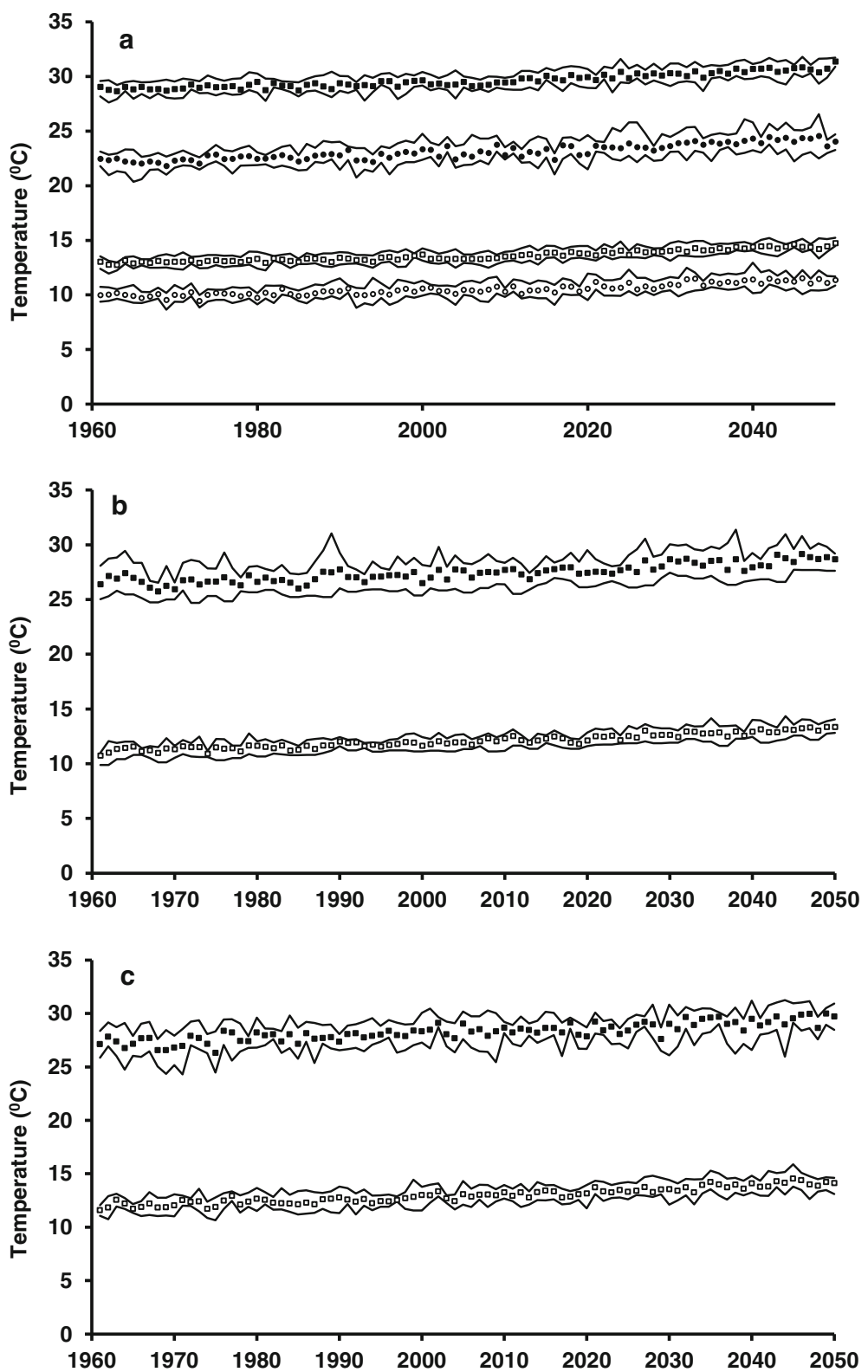

Fig. 2 Simulated maximum (black symbols) and minimum (white symbols) daily temperature for 19612050, averaged per annum. a Sandveld (white square crop growing in summer, empty circles crop growing in winter), b Eastern Free State, c Limpopo

The coefficients of determination for reference ETo are higher (between 0.19 and 0.33 ), and the trend lines show an increase over a century of 6 and $13 \mathrm{~mm}$ per season for the coastal winter and summer and up to $37 \mathrm{~mm}$ per season inland (Table 3). The increase in ETo is modest, varying between $2.2 \%$ at the coast and almost $7 \%$ in the Free State summer crop and can at least partly be 

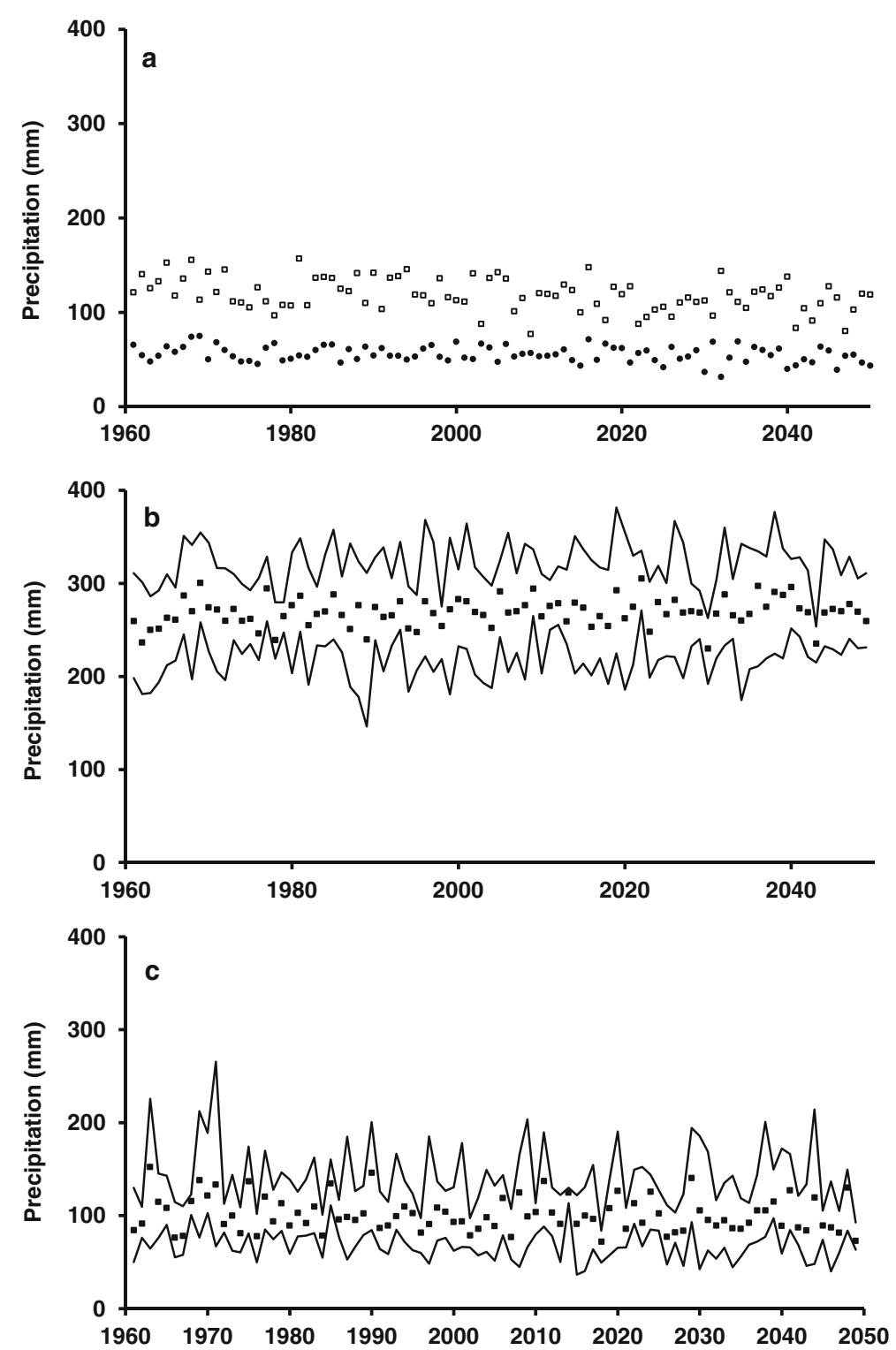

Fig. 3 Simulated precipitation during the potato cropping period for 1961-2050. a Sandveld (white square crop growing in summer, black circle crop growing in winter), b Eastern Free State, c Limpopo

explained by the increase in temperatures. The data sets show that over the 90 year period daily solar radiation decreased from 13.9 to $13.7 \mathrm{MJm}^{-2}$ day $^{-1}$ $(-1.4 \%)$ for the Sandveld winter season, and the highest decrease occurs for the Sandveld summer, from 30.0 to $29.3 \mathrm{MJm}^{-2}$ day ${ }^{-1}(-2.3 \%)$ (Table 3). Radiation levels for the Free State and Limpopo were intermediate, but the reduction was much less. Other weather parameters such as wind speed and relative humidity were not affected significantly over time, in any of the six weather sets. 

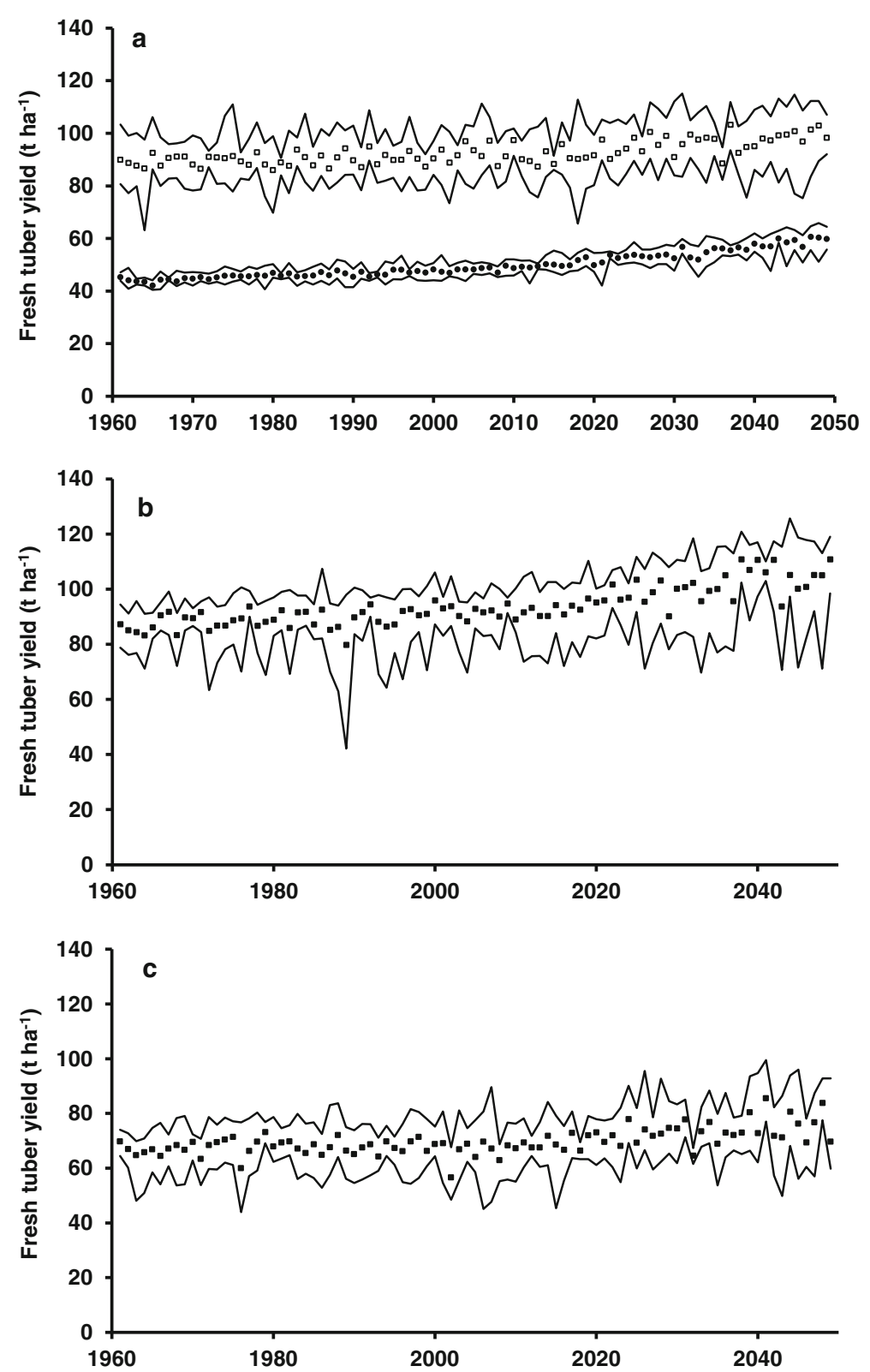

Fig. 4 Simulated potential potato yield for 1961-2050. a Sandveld (white square crop growing in summer, black circle crop growing in winter), b Eastern Free State, c Limpopo

\section{Crop Growth Model Explorations}

Potential yields for the four situations with increasing $\mathrm{CO}_{2}$ concentrations, increasing temperatures, increasing ETo values, and decreasing solar radiation are shown in Fig. 4. In all situations, yields increased, but the rate of increase differed. As discussed before, the increase in RUE is $0.15 \%$ per $\mathrm{ppm}^{\mathrm{CO}_{2}}$ increase or 



Fig. 5 Simulated precipitation deficit in potato for 1961-2050. a Sandveld (white square crop growing in summer, black circle crop growing in winter), b Eastern Free State, c Limpopo

$0.001875 \mathrm{~g} \mathrm{MJ}^{-1} \mathrm{ppm}^{-1} \mathrm{CO}_{2}$ increase (with temperatures and radiation unchanged), with $1990\left(360 \mathrm{ppm} \mathrm{CO} \mathrm{CO}_{2}\right)$ as a reference for our calculations when a RUE of $1.25 \mathrm{~g}$ $\mathrm{MJ}^{-1}$ was assumed (Kooman and Haverkort 1994). Hence, the RUE in 1960 

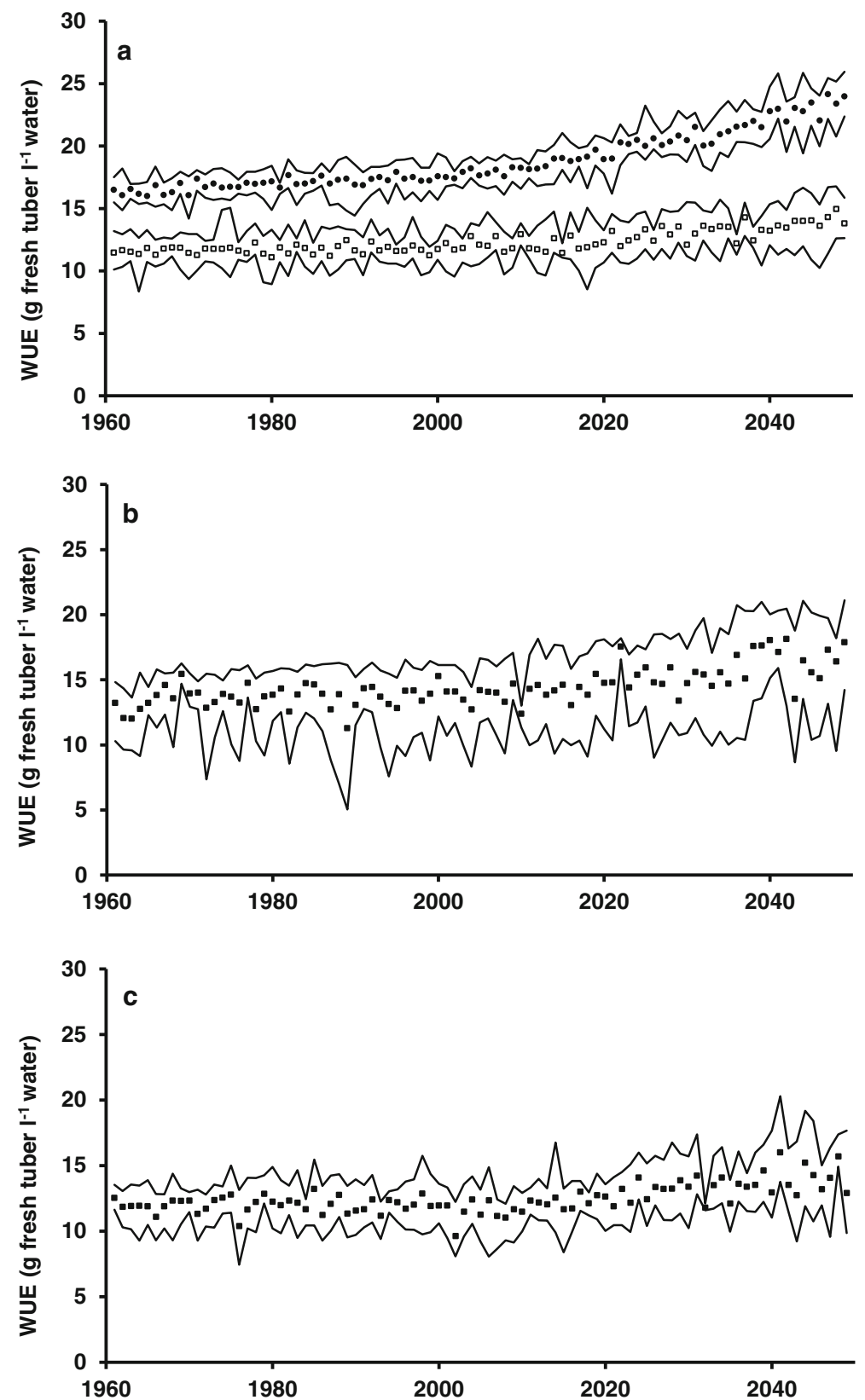

Fig. 6 Simulated water use efficiency of potato for 1961-2050. a Sandveld (white square crop growing in summer, black circle crop growing in winter), b Eastern Free State, c Limpopo

(315 ppm) was $1.17 \mathrm{~g} \mathrm{MJ}^{-1}$, and in 2050 (550 ppm), it will be 1.61. With yield proportional to RUE, a yield increase of 38\% is expected between 1960 and 2015 .

The two summer crops, intercepting most radiation (Table 3), showed the highest yields, both in 1960 and in 2050 (Fig. 4 and Table 4). The two winter crops turned out 


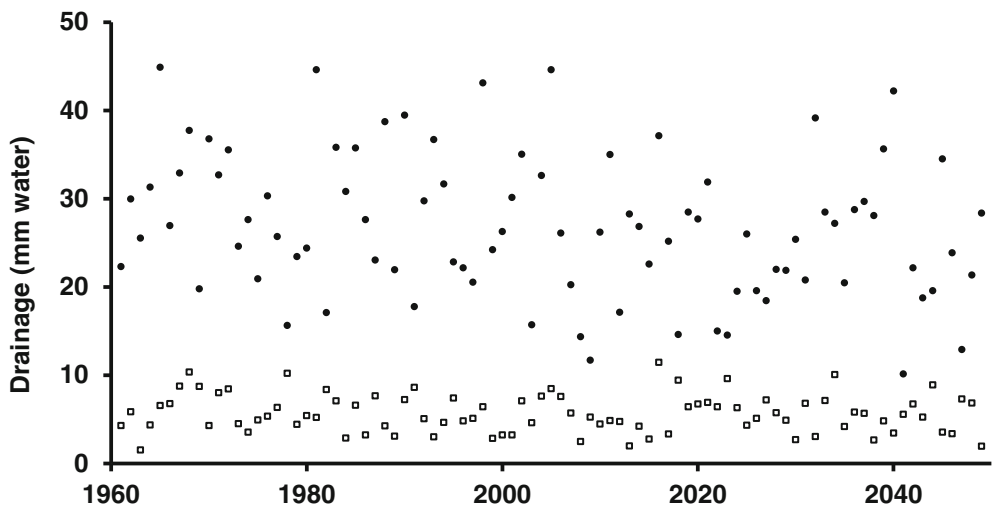

Fig. 7 Simulated drainage in potato in the Sandveld for 1961-2050 (white square crop growing in summer, black circle crop growing in winter)

to have the lowest yields, with the Sandveld substantially lower than Limpopo. The Sandveld is further south with shorter day lengths in winter and crops receiving less solar radiation than in Limpopo. The strongest relative effect of increased $\mathrm{CO}_{2}$ on yield, however, is for the Sandveld winter crop, increasing from 42.0 to $57.6 \mathrm{Mgha}^{-1}$, an increase of $37.1 \%$, close to what was predicted from the $\mathrm{CO}_{2}$ increase (corrected for the negative influence of $\mathrm{O}_{3}$ ). The next coolest site, the Free State, showed a yield increase of $23.7 \%$, and the warmer Sandveld summer and Limpopo winter showed

Table 3 Simulated minimum and maximum daily temperatures, total rainfall, reference evapotranspiration (ETo), and solar radiation during the growing season at the start and end of the range of years and average change per year

\begin{tabular}{|c|c|c|c|c|}
\hline Phenomenon & $\begin{array}{l}\text { Sandveld rainy } \\
\text { winter }\end{array}$ & $\begin{array}{l}\text { Sandveld dry } \\
\text { summer }\end{array}$ & $\begin{array}{l}\text { Free state rainy } \\
\text { summer }\end{array}$ & $\begin{array}{l}\text { Limpopo } \\
\text { dry winter }\end{array}$ \\
\hline$T \max 1960\left({ }^{\circ} \mathrm{C}\right)$ & 21.9 & 28.6 & 26.3 & 27.1 \\
\hline$T \max 2050\left({ }^{\circ} \mathrm{C}\right)$ & 24.1 & 30.6 & 28.6 & 29.5 \\
\hline$\Delta T \max \left({ }^{\circ} \mathrm{C}\right.$ year $\left.{ }^{-1}\right)$ & $0.024(0.79)$ & $0.023(0.85)$ & $0.026(0.73)$ & $0.027(0.70)$ \\
\hline $\operatorname{Tmin} 1960\left({ }^{\circ} \mathrm{C}\right)$ & 9.74 & 12.8 & 11.0 & 11.9 \\
\hline $\operatorname{Tmin} 2050\left({ }^{\circ} \mathrm{C}\right)$ & 11.3 & 14.4 & 13.1 & 14.2 \\
\hline$\Delta \operatorname{Tmin}\left({ }^{\circ} \mathrm{C}\right.$ year $\left.{ }^{-1}\right)$ & $0.0173(0.79)$ & $0.018(0.89)$ & $0.023(0.89)$ & $0.026(0.87)$ \\
\hline Rainfall in 1960 (mm) & 130.5 & 59.8 & 265 & 105.9 \\
\hline Rainfall in 2050 (mm) & 107.9 & 51.9 & 273 & 96.9 \\
\hline$\Delta$ Rainfall $\left(\mathrm{mm} \mathrm{y}^{-1}\right)$ & $-0.25(0.14)$ & $-0.09(0.07)$ & $0.10(0.03)$ & $-0.10(0.02)$ \\
\hline ETo $1960(\mathrm{~mm})$ & 197 & 611 & 529 & 504 \\
\hline ETo $2050(\mathrm{~mm})$ & 202 & 623 & 564 & 524 \\
\hline$\Delta$ ETo $\left(\mathrm{mm} \mathrm{year}^{-1}\right)$ & $0.056(0.19)$ & $0.127(0.33)$ & $0.374(0.22)$ & $0.255(0.24)$ \\
\hline Radiation $1960\left(\mathrm{MJm}^{-2}\right.$ day $\left.^{-1}\right)$ & 13.9 & 30.0 & 25.4 & 22.2 \\
\hline Radiation $2050\left(\mathrm{MJm}^{-2} \mathrm{day}^{-1}\right)$ & 13.7 & 29.3 & 25.1 & 22.1 \\
\hline$\Delta$ Radiation $\left(\mathrm{MJm}^{-2}\right.$ day $^{-1}$ year $\left.^{-1}\right)$ & $-0.002(0.17)$ & $-0.008(0.56)$ & $-0.004(0.05)$ & $-0.002(0.01)$ \\
\hline
\end{tabular}

All data are based on the average of six climate scenarios and linear regression analysis using the equation $y=a+$ $b x$ with $y$ the phenomenon and $x$ the year, $R^{2}$ of the equation is given between brackets after the change per year 
Table 4 Crop characteristics and precipitation deficit as calculated by the crop model

\begin{tabular}{|c|c|c|c|c|}
\hline Calculation & $\begin{array}{l}\text { Sandveld } \\
\text { rainy winter }\end{array}$ & $\begin{array}{l}\text { Sandveld } \\
\text { dry summer }\end{array}$ & $\begin{array}{l}\text { Free state rainy } \\
\text { Summers }\end{array}$ & $\begin{array}{l}\text { Limpopo } \\
\text { dry winter }\end{array}$ \\
\hline Yield $1960\left(\mathrm{Mg} \mathrm{ha}^{-1}\right)$ & 42.0 & 87.4 & 83.7 & 65.1 \\
\hline Yield $2050\left(\mathrm{Mg} \mathrm{ha}^{-1}\right)$ & 57.6 & 97.8 & 103.5 & 74.5 \\
\hline$\Delta$ Yield $\left(\mathrm{Mg} \mathrm{ha}^{-1}\right.$ year $\left.^{-1}\right)$ & $0.17(0.90)$ & $0.12(0.49)$ & $0.22(0.67)$ & $0.11(0.34)$ \\
\hline WUE $1960\left(\mathrm{~g} \mathrm{l}^{-1}\right)$ & 16.4 & 11.6 & 12.8 & 11.2 \\
\hline WUE $2050\left(\mathrm{~g} \mathrm{l}^{-1}\right)$ & 23.8 & 14.2 & 16.2 & 13.5 \\
\hline$\Delta$ WUE $\left(\mathrm{g} \mathrm{l}^{-1}\right.$ year $\left.^{-1}\right)$ & $0.08(0.87)$ & $0.03(0.64)$ & $0.04(0.47)$ & $0.03(0.36)$ \\
\hline$\Delta$ WUE 1960-2010 $\left(\mathrm{g} \mathrm{l}^{-1}\right.$ year $\left.^{-1}\right)$ & $0.03(0.73)$ & $0.01(0.18)$ & & \\
\hline$\Delta$ WUE 2010-2050 $\left(\mathrm{g} \mathrm{l}^{-1}\right.$ year $\left.^{-1}\right)$ & $0.14(0.92)$ & $0.06(0.66)$ & & \\
\hline ET $1960\left(\mathrm{~mm} \mathrm{season}^{-1}\right)$ & 274 & 786 & 666 & 574 \\
\hline ET $2050\left(\mathrm{~mm} \mathrm{season}^{-1}\right)$ & 258 & 722 & 652 & 551 \\
\hline$\Delta$ ET $\left(\mathrm{mm} \mathrm{season}^{-1}\right.$ year $\left.^{-1}\right)$ & $-0.18(0.45)$ & $-0.70(0.70)$ & $-0.15(0.02)$ & $-0.25(0.16)$ \\
\hline Precipitation deficit $1960\left(\mathrm{~mm} \mathrm{season}^{-1}\right)$ & 151 & 709 & 428 & 467 \\
\hline Precipitation deficit $2050\left(\mathrm{~mm}\right.$ season $\left.^{-1}\right)$ & 156 & 653 & 398 & 454 \\
\hline$\Delta$ Precipitation deficit $\left(\mathrm{mm}\right.$ season $^{-1}$ year $^{-1}$ ) & $0.049(0.01)$ & $-0.66(0.56)$ & $-0.333(0.06)$ & $0.14(0.02)$ \\
\hline
\end{tabular}

All data are based on the average outcome using the six different climate models and linear regression analysis using the equation $y=a+b x$ with $y$ the phenomenon and $x$ the year, $R^{2}$ of the equation is given between brackets after the change per year

relatively small positive responses of $12 \%$ and $14 \%$. The positive effect of $\mathrm{CO}_{2}$ is apparently partly offset by many days with $T \max$ above $30{ }^{\circ} \mathrm{C}$, having a negative effect on RUE. In the Sandveld in winter, days with high temperatures that are suboptimal for potato growth rarely occur, even with a $2.2{ }^{\circ} \mathrm{C}$ increase, while the crop is likely to benefit from higher temperatures, stimulating a more rapid initial development and reducing negative impacts of cold temperatures on RUE. The highest absolute increases in yield were found in the Free State, followed by the Sandveld winter, Sandveld summer, and Limpopo.

In general, yield variability was lower in the Sandveld in winter than in the other situations. In the Sandveld in summer, the Free State, and Limpopo, occasional heat waves could drastically reduce yields. Especially in the Free State, the minimum yield predicted could deviate considerably from the overall average. Similarly, cooler weather conditions were associated with higher yields in these situations. The climate model outcomes did not give an indication that such heat waves are more likely to occur as $\mathrm{CO}_{2}$ levels rise.

The strongest decline in ET $\left(-0.70\right.$ mmyear $\left.^{-1}\right)$ occurred for the Sandveld summer and the lowest decrease for the Free State summer $\left(-0.15\right.$ mmyear $\left.^{-1}\right)$ (Table 4$)$. The variation between years $\left(R^{2}=0.019\right)$, however, is such that this decline is not substantial. The precipitation deficit (Fig. 5, Table 4) slightly declines in the Sandveld summer, the Free State, and Limpopo (between $2.8 \%$ and $7.9 \%$ over the 90 -year period) as a result of the $13.6 \%$ reduction in water use, following partial stomatal closure due to increased $\mathrm{CO}_{2}$ concentration. The slight increase in rainfall in the Free State also helped to reduce the precipitation deficit here. In the Sandveld in 
winter, precipitation deficit slightly increased as the reduced water use by the crop did not compensate for the decreasing rainfall. In general, it can be said that water savings due to partial stomatal closure under higher $\mathrm{CO}_{2}$ concentrations are greater when evapotranspiration by the crop is high (e.g., when temperatures are high). The irrigation need was more variable in the Free State and Limpopo than in the Sandveld, reflecting the large year-to-year variation in rainfall during the growing season, especially in the Free State.

The Sandveld winter crop has the highest WUE and also shows the strongest response to increased $\mathrm{CO}_{2}$ levels, especially with the rapidly increasing levels after 2010, having an impact on both yield and evapotranspiration (Fig. 6; Table 4). The increase in WUE in winter was about four times higher in the period 2010-2050 than in 1960-2009 (from 0.034 to $0.141 \mathrm{gl}^{-1}$ year $^{-1}$ ), while in summer it increased even fivefold (Table 4). In Limpopo and the Free State, the increase in WUE was more irregular, and coefficient of determination values were lower, although here a slight acceleration in the increase in WUE after 2010 can also be observed. The WUE in the Sandveld in winter increased from 16.4 to $23.8 \mathrm{gl}^{-1}$, a $45 \%$ increase. The other locations showed WUE increase values of about half that for the Sandveld winter, mainly due to the much lower yield responses to $\mathrm{CO}_{2}$ increase in these situations, as shown in Table 4 and discussed above. Especially in the Free State, negative deviations from the general trend in WUE were sometimes large, probably as a result of heat waves during the growing period. When maximum day temperatures are above $30{ }^{\circ} \mathrm{C}$, yields are depressed and evapotranspiration is increased, both impacting negatively on WUE.

Simulated drainage in Limpopo and the Free State was minimal (data not shown), as the dominant soils there have good water holding capacity. In the sandy soils of the Sandveld, drainage is unavoidable (Fig. 7.) Drainage is highly variable from year to year and is generally higher in a winter crop than in a summer crop, reflecting the erratic nature of rainfall over years and the differences in rainfall between summer and winter. Drainage in winter slightly decreased over time as a result of gradually reducing rainfall.

\section{Discussion}

The reported exceptionally high positive response of potato (and, e.g., cassava) to elevated $\mathrm{CO}_{2}$, compared with other $\mathrm{C} 3$ crops, can be explained as follows. Firstly, Fleisher et al. (2008) observed that potato plants grown under elevated $\mathrm{CO}_{2}$ levels had consistently higher photosynthetic rates through most of the growing season and that this extra assimilate was mostly partitioned to the tubers, resulting in higher dry matter production and harvest indices, and therefore higher tuber yields. Rosenthal et al. (2012) found a very strong positive yield response to elevated $\mathrm{CO}_{2}$ levels in cassava ( $89 \%$ increase), another C 3 crop with belowground storage organs. They also ascribed the strong positive response of root and tuber crops to the fact that storage organs are formed early in the growing season, and these act as effective sinks for carbohydrates throughout most of the growing season. This continuous transport of sugars from the leaves and storing thereof as starch in the tubers avoid the negative feedback of excessive sugar concentrations on leaf photosynthesis. This confirms the 
hypothesis of Schapendonk et al. (2000) that, under higher $\mathrm{CO}_{2}$ concentration, more sugars become available in potato, enhancing the production and the activity of the sink organs, thus resulting in a substantial enhancement of final tuber yield. Cereals, on the other hand, have shorter-lived reproductive sinks that form relatively late in their growing period and therefore react less favourably, or not at all, to an increased offer of $\mathrm{CO}_{2}$.

Potential yields as simulated in this study represent a hypothetical situation where water, nutrients, and biotic factors are not limiting potato growth. Actual yields are typically about $50-70 \%$ of the potential yields in well-managed systems, as was also observed for potato farmers in the Sandveld (Franke et al. 2011). The study suggested that in all four agro-ecosystems, potential yields will increase as a result of climate change. Whether actual yields will change proportionally depends on many other factors, including farmers' ability to adjust management and crop genotypes to changing environmental conditions.

The precipitation deficits of between 150 and $710 \mathrm{~mm}$ shown in this study (Fig. 5, Table 4) are not equivalent to the irrigation need, as part of irrigation water is lost through evaporation and drainage. Actual application amounts may be between 50\% and $100 \%$ higher, depending on soil type, rainfall patterns, and whether the grower uses an irrigation decision support system. The discrepancy between calculated and actual WUE is even greater, as actual yields are lower than potential yields. If farmers achieve $65 \%$ of the potential yields, WUEs are expected to equal between $35 \%$ and $45 \%$ of the calculated values, as was observed by Franke et al. (2011) for the Sandveld region. Still, the improved WUE as a result of enhanced $\mathrm{CO}_{2}$ levels may mitigate the impact of an expected reduction in future water availability in the Sandveld due to current overuse (Archer et al. 2009) and possible declining rainfall.

We have not covered the effects of climate change on tuber quality in this study. Haverkort and Verhagen (2008) discussed the possible effects of climate change on tuber quality aspects and concluded that tuber size will increase if yields are higher while tuber numbers stay the same, dry matter concentration will be lower when average temperatures during tuber growth are higher, and reducing sugar concentration will increase when the growing season is shortened, and tubers are harvested at higher temperatures than currently. They also assumed that liberation of the markets in Europe is going to have a greater influence on where potatoes will be grown in future than shifting suitable areas resulting from climate change. Jaggard et al. (2010) s h o w e d th a t sugar beet yields in the UK increased from about $35 \mathrm{Mgha}^{-1}$ in 1975 to $50 \mathrm{Mgha}^{-1}$ in 2010, a 70\% increase due to improved crop management and improved varieties. A similar trend has been seen for South African potato production over the past 20 years (Potatoes South Africa 2011). The area under production has declined from about 66,000 ha in 1991 to about 51,000 ha in 2010. However, over this period, average yields have nearly doubled from 21.2 to $41.2 \mathrm{Mgha}^{-1}$. These higher yields are mainly attributed to improved management practices, a substantial shift from rain-fed to irrigated cropping (from about $49 \%$ irrigated in 1992 to $86 \%$ of the total area in 2010) and new cultivars. These steep yield increases have started levelling off over the past 4 years. In the present analyses, we did not include such improved management and product quality aspects, but they will likely affect usable yield and finished product over the next 40 years, as significantly as the yield increase expected from the greater availability of $\mathrm{CO}_{2}$ and improved water use efficiency. We did also not discuss here 
the effect of climate change on the length of the growing season, optimal planting and harvest times, and the effect thereof on production and resource use efficiency. That subject will be discussed in a following paper (Franke et al. 2013). Furthermore, we did not explore the influence of climate change on pests and diseases of potato, which is also addressed in a subsequent paper (Van der Waals et al. 2013).

\section{Final Conclusions}

It is concluded that, for all four contrasting agro-ecosystems, the possible negative effects of future raising temperatures and reduced availability of water will be more than compensated for by the positive effect of increased $\mathrm{CO}_{2}$ on potential water use efficiency and crop productivity. Therefore, we reject the hypothesis that, given the expected increase in average temperatures for southern Africa and the sensitivity of potato to heat stress, the impact of climate change on potato production and water use efficiency will be negative. The beneficial effect of $\mathrm{CO}_{2}$-enrichment for potatoes is much stronger than for cereals that generally benefit less or not at all from increased $\mathrm{CO}_{2}$-levels (e.g., Elsgaard et al. 2012). The importance of potato as a climate change robust crop for food security is, therefore, likely to increase in the decennia to come.

Acknowledgments We thank Potatoes South Africa and The Netherlands Ministry of Economic Affairs, especially Prof. Nico Visser, Agricultural Counsellor at The Netherlands Embassy in Pretoria until mid2012, for financial support.

\section{References}

Allen RG, Smith M, Pruitt WO, Pereira LS (1996) Modifications to the FAO crop coefficient approach. Proc. Int. Conf. Evapotranspiration Irrigation Scheduling, San Antonio, Texas, USA, pp 124-132

Archer ERM, Conrad J, Munch Z, Opperman D, Tadross MA, Venter J (2009) Climate change and commercial agribusiness in the semi-arid northern Sandveld, South Africa. J Integr Environ Sci 6:139-155

De Temmerman L, Hacour A, Guns M (2002) Changing climate and potential impacts on potato yield and quality 'CHIP': introduction, aims and methodology. Eur J Agron 17:233-242

Eamus D (1991) The interaction of rising $\mathrm{CO}_{2}$ and temperatures with water use efficiency. Plant Cell Environ 14:843-852

Elsgaard L, Børgesen CD, Olesen JE, Siebert S, Ewert F, Peltonen-Sainio P, Rötter RP, Skjelvåg AO (2012) Shifts in comparative advantages for maize, oat, and wheat cropping under climate change in Europe. Food Addit Contam Part A 29:1514-1526. doi:10.1080/19440049.2012.700953

Engelbrecht FA, McGregor JL, Engelbrecht CJ (2009) Dynamics of the conformal cubic atmospheric model projected climate-change signal over southern Africa. Int J Climatol 29:1013-1033

Engelbrecht FA, Landman WA, Engelbrecht CJ, Landman S, Roux B, Bopape MM, McGregor JL, Thatcher M (2011) Multi-scale climate modelling over southern Africa using a variable-resolution global model. Water SA 37:647-658

Engelbrecht CJ, Engelbrecht FA, Dyson LL (2013) High-resolution model-projected changes in midtropospheric closed-lows and extreme rainfall events over southern Africa. Int J Climatol 33:173-187

Fleisher DH, Timlin DJ, Reddy VR (2008) Elevated $\mathrm{CO}_{2}$ and water stress effects on potato canopy gas exchange, water use, and productivity. Agric For Meteorol 148:1109-1122

Franke AC, Steyn JM, Ranger KS, Haverkort AJ (2011) Developing environmental principles, criteria, indicators and norms for potato production through field surveys and modelling. Agric Syst 104:297-306

Franke AC, Haverkort AJ, Steyn JM (2013) Climate change and potato production in contrasting South African agro-ecosystems 2. Assessing risks and opportunities of adaptation strategies. Potato Res 56. doi:10.1007/ s11540-013-9229-X 
Haverkort AJ, Verhagen A (2008) Climate change and the repercussions for the potato supply chain. Potato Res 51:223-237

Hijmans RJ (2003) The effect of climate change on global potato production. Am J Potato Res 80:271-279

Jaggard KW, Qi A, Ober AA (2010) Possible changes to crop yield by 2050. Phil Trans R Soc Bot 365:2835-2851

Kooman PL, Haverkort AJ (1994) Modelling development and growth of the potato crop influenced by temperature and daylength: LINTUL-POTATO. In: Haverkort AJ, MacKerron DKL (eds) Ecology and modeling of potato crops under conditions limiting growth. Kluwer Academic Publishers, Dordrecht, pp 41-60

Magliulo V, Bindi M, Rana G (2003) Water use of irrigated potato (Solanum tuberosum L.) grown under free air carbon dioxide enrichment in central Italy. Agric Ecosyst Environ 97:65-80

Miglietta F, Magiulo V, Bindi M, Cerio L, Vaccari FP, Loduca V (1998) Free Air CO2 Enrichment of potato (Solanum tuberosum L.): development, growth and yield. Global Chang Biol 4:163-172

Nakicenovic N, Swart R (2000) Special report on emission scenarios. A special report of Working Group III of the Intergovernmental Panel on Climate Change. Cambridge University Press, Cambridge

Nakicenovic N, Alcamo J, Davis G, de Vries B, Fenhann J, Gaffin S, Gregory K, Griibler A, Yong Jung T, Kram T, La Rovere EL, Michaelis L, Mori S, Morita T, Pepper W, Pitcher H, Price L, Riahi K, Roehrl A, Rogner HH, Sankovski A, Schlesinger M, Shukla P, Smith S, Swart R, van Rooijen S, Victor N, Dadi Z (2000) Intergovernmental Panel on Climate Change (IPCC) Special Report on Emissions Scenarios. Cambridge University Press, Cambridge, pp 85-89, http://www.ipcc.ch/pdf/special-reports/emissions_scenarios.pdf

NASA (2013) http://climate.nasa.gov/uncertainties (accessed January 2013)

Pospisilova J, Catsky J (1999) Development of water stress under increased atmospheric CO2 concentrations. Biol Plant 42:1-24

Potatoes South Africa (2011) SA Potato industry-hectares and crop size. http://www.potatoes.co.za/ industry-information/national-annual-information.aspx (accessed Jan 2013)

Ritchie JT (1972) Model for predicting evaporation from a row crop with incomplete cover. Water Resour Res 8:1204-1213

Rosenthal DM, Slattery RA, Miller RE, Grennan AK, CavagnaroTR FCM, Gleadow RM, Ort DR (2012) Cassava about-FACE: greater than expected yield stimulation of cassava (Manihot esculenta) by future CO2 levels. Global Chang Biol 18:2661-2675

Rosenzweig C, Hillel D (1998) Climate change and the global harvest: potential impacts of the greenhouse effect on agriculture. Oxford University Press, New York, $862 \mathrm{pp}$

Schapendonk AHCM, Pot CS, Goudriaan J (1995) Simulated effects of elevated carbon dioxide concentration and temperature on the productivity of potato. Interaction with cultivar differences for earliness. In: Haverkort AJ, MacKerron DKL (eds) Ecology and modelling of potato crops under conditions limiting growth. Kluwer, Dordrecht, pp 101-117

Schapendonk AHCM, van Oijen M, Dijkstra M, Pot SC, Jordi WJRM, Stoopen GM (2000) Effects of elevated $\mathrm{CO} 2$ concentration on photosynthetic acclimation and productivity of two potato cultivars grown in open-top chambers. Aust J Plant Physiol 7:1119-1130

Smith M, Allen RG, Pereira LS (1996) Revised FAO methodology for crop water requirements. Proc. Int. Conf. Evapotranspiration and Irrigation Scheduling, San Antonio, Texas, USA, pp. 133-140

Spitters CJT (1990) Crop growth models: their usefulness and limitations. Acta Horticult 267:349-368

Spitters CJT, Schapendonk AHCM (1990) Evaluation of breeding strategies for drought tolerance in potato by means of crop growth simulation. Plant Soil 123:193-203

Supit I, Van Diepen CA, De Wit AJW, Wolf J, Kabat P, Baruth B, Ludwig F (2012) Assessing climate change effects on European crop yields using the crop growth monitoring system and a weather generator. Agric For Meteorol 164:96-111

Taljaard JJ (1986) Change of rainfall distribution and circulation patterns over Southern Africa in summer. Int J Climatol 6:579-592

Van der Waals JE, Franke AC, Haverkort AJ, Krüger K, Steyn JM (2013) Climate change and potato production in contrasting South African agro-ecosystems 3. Effects on relative development rates of selected pests and pathogens. Potato Res 56. doi:10.1007/s11540-013-9231-3

Vorne V, Ojanperä K, De Temmerman L, Bindi M, Högy P, Jones MB, Lawson T, Persson K (2002) Effects of elevated carbon dioxide and ozone on potato tuber quality in the European multiple-site experiment 'CHIP-project'. Eur J Agron 17:369-381

Wolf J, Van Oijen M (2003) Model simulation of effects of changes in climate and atmospheric CO2 and O3 on tuber yield potential of potato (cv. Bintje) in the European Union. Agric Ecosyst Environ 94:141-157

Yin X, Struik PC (2008) Applying modelling experiences from the past to shape crop systems biology: the need to converge crop physiology and functional genomics. New Phytol 179:629-642 